\title{
Landscape Painting in Turkish Art of Painting and Periodical Reflections
}

\author{
Birsen Çeken ${ }^{1}$, Asuman Aypek Arslan ${ }^{2}$ \\ ${ }^{I}$ (Graphic Design Department, Art and Design Faculty/Gazi Üniversity, Turkey) \\ ${ }^{2}$ (Visual Arts Department, Art and Design Faculty/ Gazi University, Turkey)
}

\begin{abstract}
The landscape is an indispensable subject of our painting art just as like the nature which is an indispensable part of the life of human being. In spite of the different movements and applications in the development line, the nature has maintained its dominant place in the art and it has taken place in the values that shaped the art. The landscape painting among the paintings of the Turkish painters shows that the natural scenes were given importance subject and so the number of the paintings with this subject was great. Our getting acquaintance with the painting as an eastern community has led us to paint with our senility towards the natural scenes. Our first paintings that did not carry the signatures of our painters because of the sensitivity of the painters' who dealt with the landscapes with an admiring manner that felt afraid to touch the nice landscapes which are created by god with beauty had social values that they did want to put their names before the community. Compositions, still life and even nude paintings that included different points of view towards the natural appearance as well as including landscapes. The natural views have remained in the paintings as indispensable values. Even the abstract paintings that have emerged as a result of the fast flow of the development are abstract paintings of the nature. In this study, the landscape painting in the Turkish Painting Art and its periods in the development period will be dealt with.
\end{abstract}

\section{Keywords: Turkish Painting, Landscape Paintings}

\section{INTRODUCTION}

The passion to nature has been reflected in miniatures since $16^{\text {th }}$ century in the life of Turks and they gradually comprised the first samples of canvas paintings in the following process.

Turkish painters have been trained in an atmosphere that could be expressed as the passion to nature so open to nature in an environment where landscape painting rather than figures are of importance within the efforts of compulsory cultural change in $19^{\text {th }}$ century. The training field dominated by military schools at first was followed by civil schools. On the other hand, it is likely to see that some of the Turkish artists going to Western ateliers for the painting education regarded landscape as a problem beyond photography and attempted to produce something in this sense. There are numerous unsigned paintings among the first examples of Turkish painting. The paintings exhibited in Istanbul Painting and Sculpture Museum, of which painters are not known, could be regarded in this context. In this sense, landscape is of great importance in terms of Turkish painting, since it has become significant in terms of creating an opportunity to make and observation and research. Besides that, using the same visual texture led the artists in this period to produce a common sense of art.

In the works of art whose artist is unknown, in other words, the works which were not signed, and in the ones whose artists are known, such common sensibilities as conveyance of landscape up to choosing the subject have always been on the agenda. The result obtained here is that the landscape paintings painted in that period was of a quality of a document and that they had a descriptive characteristic. Our acquaintance with painting as an Eastern community would lead us to turn directly to landscape painting as a result of traditional structure and social values. While the theme of landscape was regarded in a dimension depending on observation within the development of Turkish painting before the period of Republic, there became a change in landscape painting after Republican period as a result of the connections with Europe and our interest in modern art. In particular, even after our acquaintance with abstract painting, nature depictions were taken into consideration and it soon became original comments with the individual tendencies of the artists of landscape painting. In this sense, abstract painting turned into different ways of expressions starting from a dimension based on observation with nature section.

The period when landscape painting was so common and popular in the West is the same time when landscape painting was also so popular in Turkey. This interest is just a similarity in terms of the tendency to landscape. The young painters trained in this system come to the fore as the artists putting a priority and significance on landscape paintings. The young trained in the mystic structure of the eastern philosophy were so neat in transferring the "untouchable" admiration that they considered as the creation God into their canvas. In 
the landscape paintings of these painters, Istanbul where they live is an indispensable subject even though they sometimes choose some different other cities they visit as their topic. Depicting the palaces of Istanbul, the gardens in the palaces and historical monuments means an honourable and respectable art work for them. Being able to enter the streets of the city, being inside daily life is already an imagination that the young living behind the high walls of dormitory schools cannot realize. After their graduation very few was able to dare to paint such things.

\section{LANDSCAPE PAINTING IN TURKISH ART OF PAINTING AND PERIODICAL REFLECTIONS}

The painters having produced the first samples of our art of painting are known with their landscape painter identities. Nature views are the samples of $19^{\text {th }}$ century painting as mostly encountered topics, particularly forest paintings. Istanbul landscapes are dominant among urban landscapes. The school initiated among the innovations considered in the military schools before the period of reforms put a new branch of art, the emergence of painting art on the agenda for the Ottoman. This initiative was first followed in civil schools and then added in the program as painting courses (Cezar, 1995). In the four year program of Hendese-i Mülkiye (1859) (Technical University), painting courses were also taught.

It is true that painting courses were of great importance in such secondary educational institutions as Darüşşafaka High School that was reconstructed in 1872. It is difficult to define the painters trained in this school as they did not use their surnames in this period. As an example, Ahmet Emin from Hasköy and Emin were two military painters living in the same years. Ferik İbrahim Pasha, Ferik Tevfik Pasha and Hüsnü Yusuf were the first Turkish painters to be sent to Europe for the purpose of education (Edhem, 1970). They were followed by Şeker Ahmet Pasha, Süleyman Seyit and Osman Nuri Pasha.

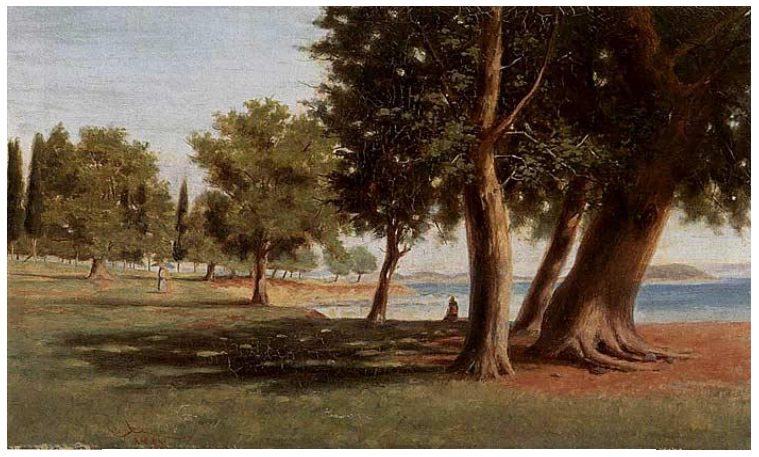

Süleyman Seyit, Fenerbahçe Landscape

Of the military painters having a landscape painting, the majority of those graduating a military academy is remarkable. At this stage, it is clear that the artists having had a chance to go to Europe are different from the others (Yetik, 1940). The artists trained in this system are the ones putting an importance and priority on landscape paintings. The artists also trained within the mystic structure of oriental philosophy transferred their admiration to the nature created by God into their canvas with their comments based on detail and observation. Even though they sometimes used the urban landscapes their visited as their subjects, they mostly focused on Istanbul. Depicting the palaces of Istanbul and historical monuments means an honourable and respectable art work for them (Giray, 1998). Among the artists transferring their comments based on detail and observation are Nuri Pasha, Kosovalı Hayri, Ahmet Bedri, Mehmet Hayri and Hoca Ali Riza.

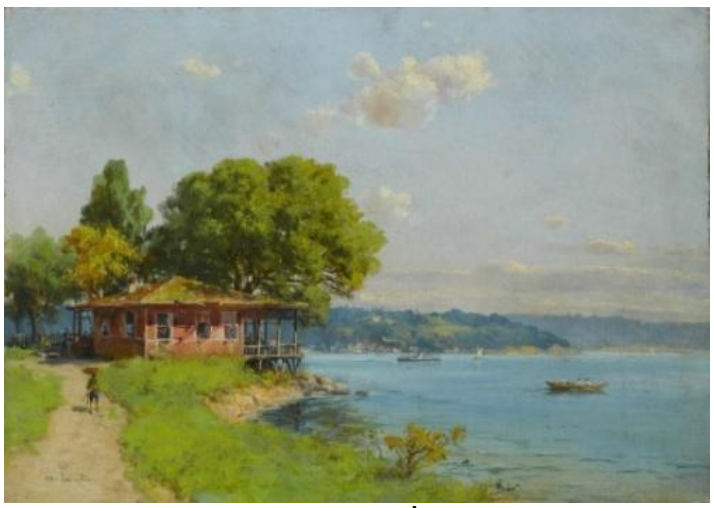

Hoca Ali Rıza, İstanbul 
It is striking in most of the oil paintings that Yldiz Palace was depicted and that these paintings are as if they were painted by the same person and look like a photograph. Even the paint tissues and colour choice of the painters are the same. All these similarities lead us to an atelier, Darüşşafaka ateliers. It was found by the researcher that these paintings were painted in the atelier in front of photography. The fact that there are similarities as if they were painted by the same painter with common technique and application and that they have the same paint tissue and colour values prove that the painters working in the same atelier privately designed and supervised produced paintings looking at a photography in the local atmosphere of this atelier (Tansuğ, 1980). It is likely to mention Salih Molla Aşki, Kasımpaşalı Hilmi, Lofçalı Ahmet and Ahmet Ragıp in this category.

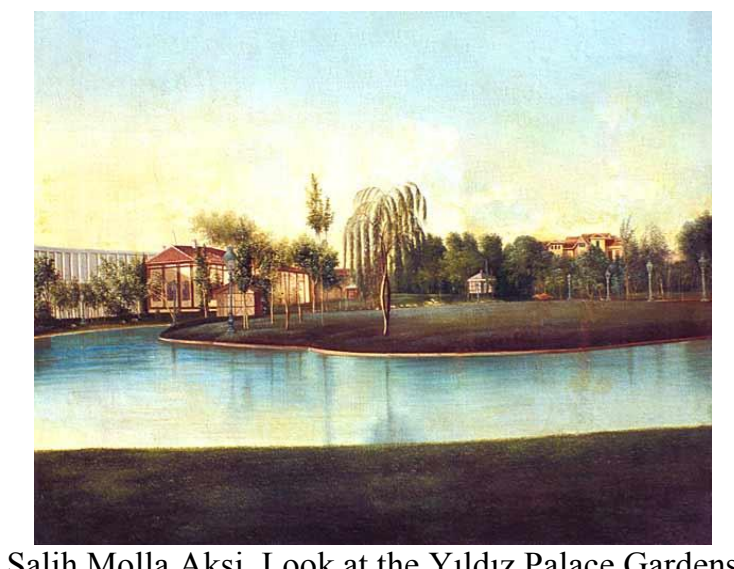

Salih Molla Akşi, Look at the Yıldız Palace Gardens

It is also likely to see that the artists living in the same life span, starting their painting education at the same school but going to different European cities with the scholarships they were awarded brought new comments to landscape painting when they turned back. This process led to the start of Western influence (Anonymous, 1939). Şeker Ahmet Pasha and Halil Pasha are the painters working in the G. Boulanger, j. Gerome Fine Art Academy in Paris.

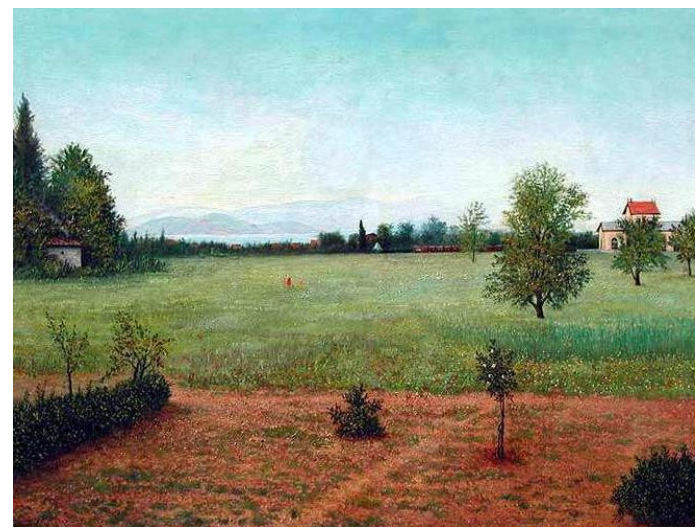

Şeker Ahmet Paşa. Erenköy

The community started to be enlightened through science and art schools in the period of Abdulhamid II, in other words in the period of Meşrutiyet (Reformation). With the adaptation of the schooling systems comprising the bases of the Western development, radical cultural changes appeared at Ottoman State. This change was also seen in the Palace with the emergence of new types of art instead of traditional ones (Giray, 1998). The most important one was that plastic arts were directly adopted by the Ottoman Palace. The biggest even at the age for the sake of art was that Sanayi-i Nefise Mektebi (Fine Arts School) was opened by Osman Hamdi Bey (1882). In comparison with the paintings opening to the exotic world of the east by Western painters, Osman Hamdi commented the values he know and even experienced with regard to the life characteristics of his own community and produced paintings with orientalist inclinations. He reached the values separating from the paintings of orientalist inclinations with this approach (Cezar, 1995). Osman Asaf, Şevket Dağ, Mehmet Agah Özbulan were among the first graduates of Sanayi-i Nefise Mektebi. It is likely to add Celal Esat Arseven, Mehmet Ali Lage, Sami Yetik, Mehmet Ruhi Arel in the group of artists depending on observation but seeking something new. 


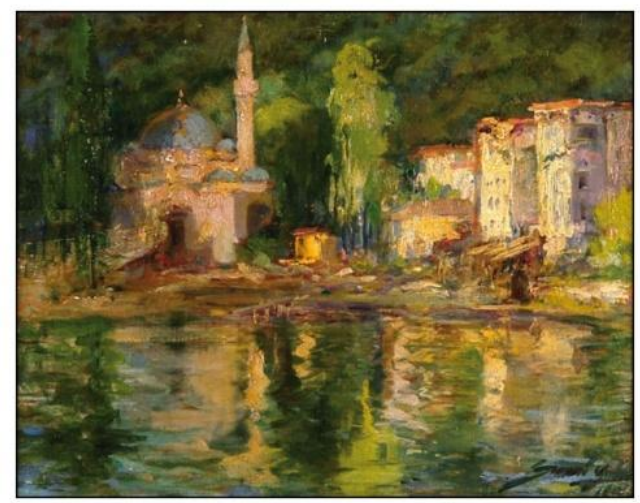

Sami Yetik, Bebek

The fact that our artists transferred what they saw directly on the canvas, their struggle to produce a similar one of what was on the photo shows that Ottoman community had a closed system of thought, however, painting in this system of the community means the start of a new era. In this sense, the subject matters our painters used directly related to the traditional system of thought (Tahsin, 1960). It cannot be ignored that Sanayi-i Nefise Mektebi had a prominent place in the fact that Turkish painting opened itself a new window and attaining an identity of artist. In 1914, it is likely to see that the consciousness of being an artist could be seen in our artists. In this period, the artists turning to the country back from European training commented the nature with the visual effect created by light changes. Even the artists' ignorance of the untouchable attitude of Ottoman thought towards the God created nature could be seen a great step. Another step was the depiction of everyday life events. The interior of houses and mosques, and figures, even woman figures, started to appear on the canvases and it was the leading art step for the development of this era (Giray, 1998). The representatives of this art period know as 1914 generation or Çallı generation are İbrahim Çallı, Avni Lifij, Namık İsmail, Nazmi Ziya Güran, Feyhaman Duran, Hikmet Onat in our art of painting.

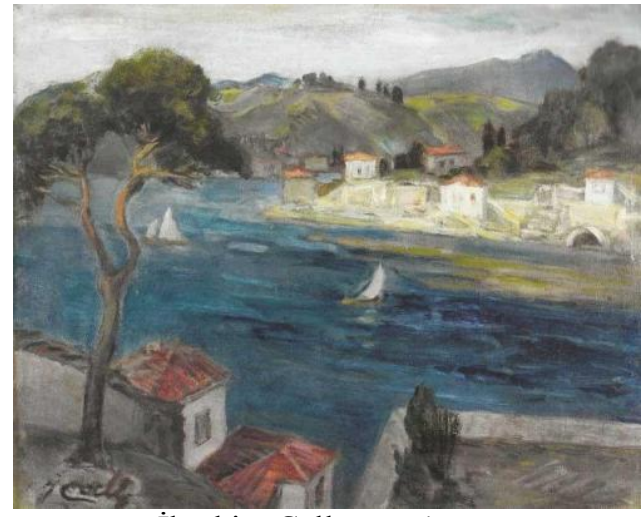

İbrahim Çallı, Landcape

The second importance change in the development line of Turkish painting art was experienced in the late 1920s and early 1930s. It is known that this period which is indicated as the start of modern age in Turkish painting survived within the modernization program brought by the establishment period the Republic. People trained with the consciousness of being an artist started to improve themselves as a product of art movements and free thoughts. This teaching started to gain new meanings at the stage of getting to know the products of impressionist artists of Hoffman School and Germany, and being aware of the paintings expressing the artistic views of Cezanne. The artists in this period were introduced to the values which disinformation made them attain meaning and started to paint by searching for the distribution of stain and natural hues by Cezanne and his teaching of cubism.

In addition, new realism emerging in France and America started to be seen in the paintings in late 1930s. Particularly, there were samples having two different views between these views within the new realism. Some artists adopted the sense of idealist realism (Çoker, 979). At this stage, painter purified the nature part to be depicted from the subjective reality and reached an expression aligned to the construction he loaded to the fiction of the painting suitable to his own taste. The second choice reflected upon Turkish painting within the new realism appears as the values contradicting with the universal view of realism. At this stage, the paintings painted for the state or the institutions became the agenda. Instead of the painting for the upper class, realistic 
comments were studied in the paintings that were expected to express to every level of the community, to people, worker, people at certain educational level. In particular, Turkish painters participating in the domestic expeditions of CHP (Republican People's Party), Production Paintings Competition of Yap1 Kredi Bank, Revolution Paintings Exhibitions arranged for the purpose of establishing Revolution Museum or State Exhibitions as competitive and ordered painting production started to produce their own paintings reflecting their own sense of art within realist painting applications. Among the painters of this period are Şeref Kamil Akdik, Ahmet Zeki Kocamemi, Refik Fazıl Ekipman, Hale Asaf, Hamit Görele, Şefik Bursalı.

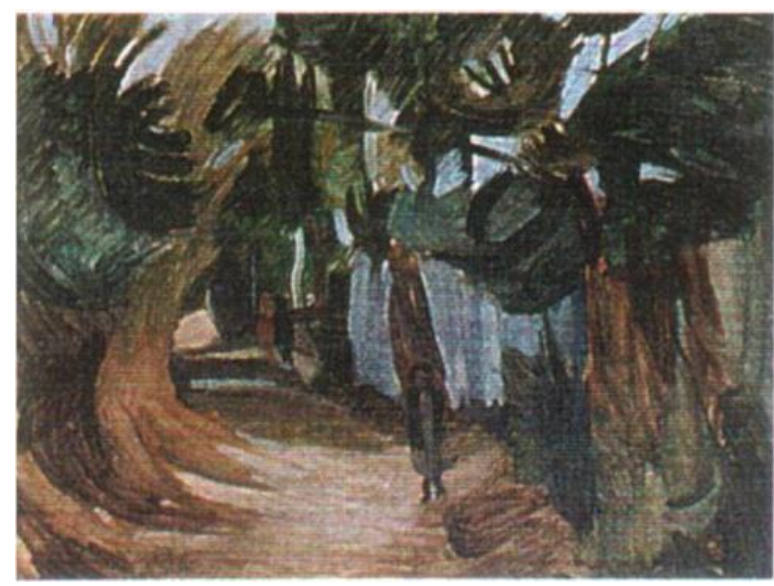

Ahmet Zeki Kocamemi, Parkway

Turkish art of painting witnessed art views within the seeking of a new modernity in the period of late 1930 s and in 1940s up to 1950s. At this stage, Turkish painting was influenced by Lhote and Legar atelier, two important ateliers of the West (Giray, 1983). The artists studied analytic theory and form analysis, making an observation in these two atelier and they reflected geometric abstractions in their paintings. At this stage, another artist from whom Turkish artists were influenced was Matisse and his comments regarding motive. In 1931, artists were in an effort to practice what they learned from the West and in this while they investigated the history of thought in their writings and carried out their philosophical views which were needed for art on the way of modernization as a whole. Following the World War II, it was almost the same time when national sense of art started to be clearer. Elif Naci, Cemal tollu, Zeki Faik İzer, Nurullah Berk, İsmail Ercüment Kalmık, Sabri Berkel, Bedri Rahmi Eyüpoğlu are the artists of this era.

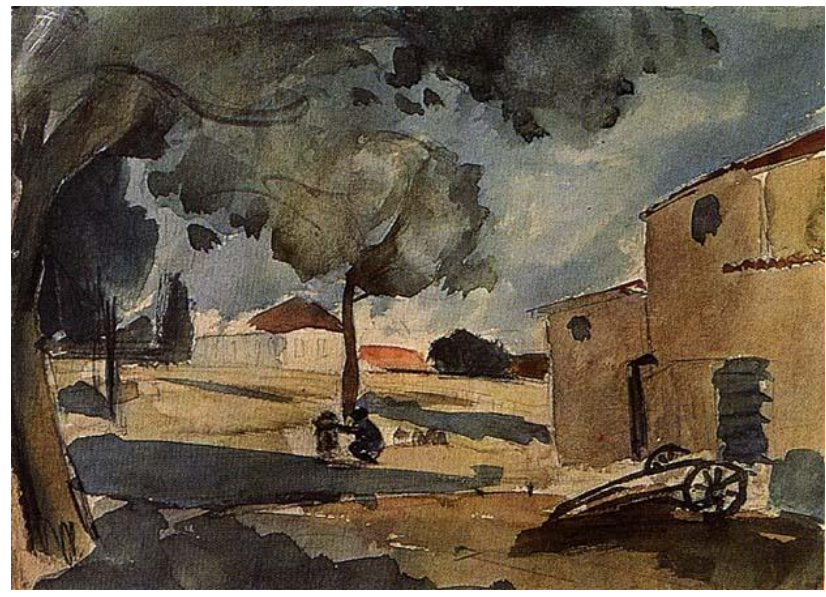

Cemal Tollu, Around Bursa

Young painters graduating from the Academy following 1940s gathered around two different views. The first one was to determine only one subject as a new enterprise and painting with the comments within the content of this subject, and the other one was to follow a non-figurative tendency (İzer, 1940). Following 1960 revolution in Turkey, it was observed that the interest felt for social reality increased and the samples of this movement were produced in all branches of art from literature to movie, from theatre to poetry. Nuri İyem, Avni Arbaş are the pioneer of this movement. 


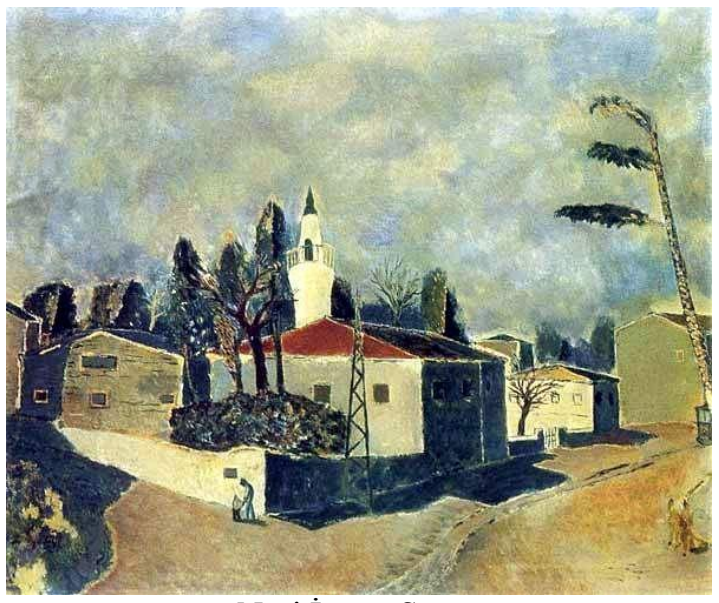

Nuri İyem, Street

The pioneer of paintings based on traditional sources once again in Turkish painting was Malik Aksel. He was followed by Turgut Zaim and Bedri Rahmi Eyüpoğlu (Tansuğ, 1991). These artists tried to reach a synthesis adding traditional Turkish motives to the peinture technique of the West and defended making Turkish painting reach its authentic identity. In his essays writing for the book "Young Painters" they prepared with the group "On'lar Grubu" (Group of Tens) made up of students, Bedri Rahmi Eyüpoğlu indicated our handicraft arts as the most important source of our art of painting (Giray, 1998).

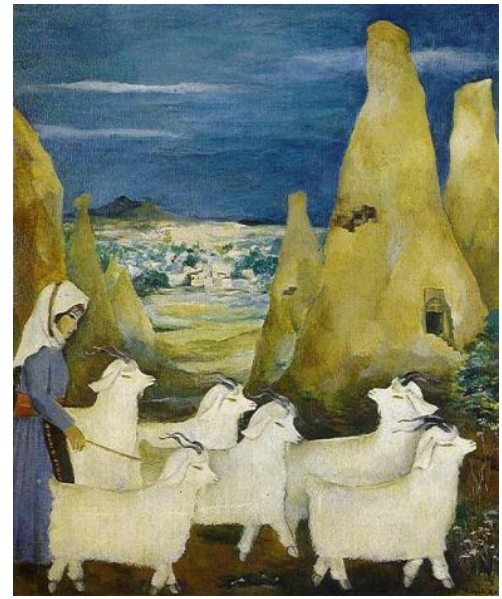

Turgut Zaim

1940s were the period when abstract expressions were increasingly investigated and applied in Turkish painting as in the West. In the core of abstract applications lied the freedom of artist sensibility. The artist tends to creating the objects he faces while depicting the subject he determines or nature appearance in the light of individual sensibility. For that reason, abstract expressions are regarded as a superior power of thought. In this period, artists started to produce their abstract applications as nature abstractions and painted with stain, lyric or geometric abstractions or so. Ferruh Başağa, Devrim Erbil, Orhan Peker and Turan Erol are the artists painting in this sense.

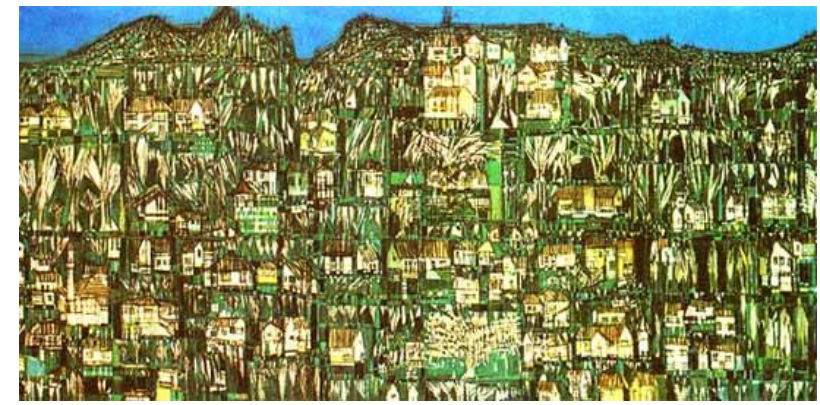

Devrim Erbil 
In the years 1950s, we observed that free democracy brought innovations to Turkey in every aspect. In particular, the art of painting and sculpture were enriched with new painting facilities and turned their face to abstract painting. It was a very important development in terms of Turkish painting. Nevertheless, there became some challenges to make the people adopt the abstract painting. A great many artists in Turkey, particularly some artists painting with social content interested in abstract painting.

In this group of artists were the ones with a tendency to abstraction as well as those considered in the Group of Tens. Besides this group, the middle aged artists in the Group D and the Union of Independent Painters and Sculpts started to join in this abstract movement. Among these artists are Hadi Bara, Zühtü Müridoğlu, Sabri Berkel, Zeki Faik İzer, Nurullah Berk, Halil Dikmen, Refik Epikman, Hamit Görele, Ercüment Kalmık and Bedri Rahmi Eyüboğlu, in particular.

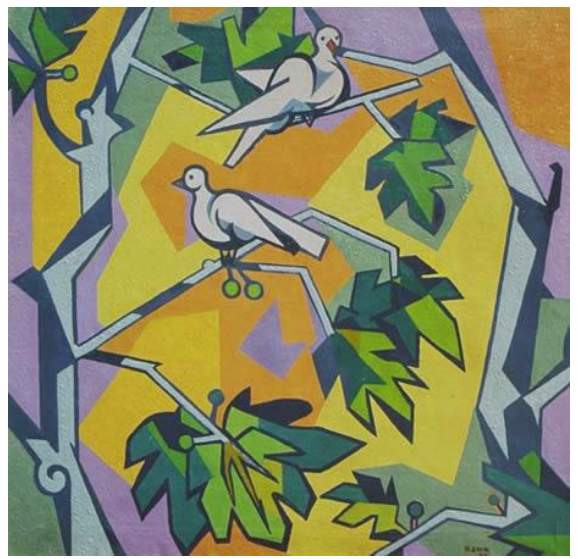

Nurullah Berk

\section{CONCLUSION}

The great majority of Turkish painters had an inclination to landscape painting. In other words, Turkish painting came to the fore with its characteristic of landscape painting. It is known that a great many painters tried landscape painting before and after Republican period and that particularly the ones painting in abstract style used nature painting within the concept of abstraction. In this context, the development course of Turkish painting art also means the development course of both abstract painting and the development and changing in landscape painting.

In this way, landscape sensibility appeared within all seeking for styles from the first samples determining the admiration onwards for the untouchable beauty of nature. As an example, while landscape takes its place in the background of a nude or still life painting within the content of all art movements, it mostly appears as a nature image in providing the infrastructure of a composition. The landscape image in terms of abstract painting or the nature theme in the way of a change in Turkish painting opened a field where Turkish artists can express themselves. These artists discovered various styles and colour abstractions not only from the point of view inspired from trees in nature or sea view but also benefitting from the visual effects brought by different cultures and architectural buildings while creating a plastic texture giving priority to style and colour laws in nature abstractions.

In this way, the artists producing abstract paintings in the way to develop abstract painting revealed different creative effects. The inspirations attained in nature triggered original comments while artists created the products their subjective sensibilities thanks to their landscape sensibilities.

\section{REFERENCES}

[1]. Anonimous. (1939). "Ressam Halil’in Ölümü”. Güzel Sanatlar İkinci teşrin. P.138.

[2]. Cezar, Mustafa. (1995). "Sanatta Batıya Açılıș ve Osman Hamdi”. Paris.

[3]. Çoker, Adnan. (1979). “Kocamemi’nin Özgeçmişi”. Zeki Kocamemi Catalogue. p. 60. İstanbul.

[4]. Edhem, Halil. (1970). "Elvah-1 Nakşiye Koleksiyonu”. Translation.G. Elibal. İstanbul.

[5]. Giray, Kiymet. (1983). "Avni Abraş”. Yeni Boyut. p.2-18. s.23.

[6]. Giray, Kıymet. (1998). "İş Bankası Koleksiyonu". İstanbul.

[7]. İzer, Zeki Faik. (1940). “Genç Sanatçıların Sergisi”. Güzel Sanatlar. May. p.2. s.167.

[8]. Tahsin, Orhan. (1960). “Ölümünden 13 Gün Sonra Hayatını Kendi Sesinden Dinlediğim İnsan: İbrahim Çallı. Hayat. 10 June. p.24. p.8-9.

[9]. Tansuğ, Sezer. (1980). "Resim Sanatımızda Ortaya Çıkan Yeni Bir Gerçek, 19yy. Sonu Foto Yorumcular”. Sanat Çevresi. September. p.23. p.5-6.

[10]. Tansuğ, Sezer. (1991). "Çağdaş Türk Sanatı". İstanbul.

[11]. Yetik, Sami. (1940). "Ressamlarımız". Volume 1. İstanbul. 